\title{
INVESTIGATION OF RAINWATER HARVESTED FROM DIFFERENT PARTS OF BENIN METROPOLIS, EDO STATE, NIGERIA.
}

\author{
${ }^{1 * I m h o n t u, ~ M . U ., ~}{ }^{2}$ Ukpebor, E.E., ${ }^{3}$ Biose, $O$. \\ ${ }^{1,3}$ National Centre for Energy and Environment, Energy Commission of Nigeria, University of Benin, Benin City, Edo State, \\ Nigeria \\ ${ }^{2}$ Department of Chemistry, University of Benin, Benin City, Edo State, Nigeria \\ Corresponding author's: reemzy2001@yahoo.co.uk,bosadebe@yahoo.com \\ $+234-8061517804,+234-8062151153$
}

DOI: $10.31364 / \mathrm{SCIRJ} / \mathrm{v} 7 . \mathrm{i} 3.2019 . P 0319625$

http://dx.doi.org/10.31364/SCIRJ/v7.i3.2019.P0319625

\begin{abstract}
The paper investigates trace metal concentration in rainwater from four locations namely: New Benin, Ring Road, University of Benin Campus and Oluku areas all situated in Benin Metropolis of Edo State, Nigeria. PerkinElmer Optima 5300DV inductively coupled plasma - optical emission spectrometry (ICP-OES) was utilised for chemical analysis of Aluminium, Calcium, Potassium, Magnesium, Sodium, Silicon, Tin, Strontium, Boron and Sulphur. The results of conductivity range of 5.65-83.15 $\mu$ Scm- ${ }^{1}$ and mean pH range of 5.47-6.76 obtained from rainwater samples establishes that some of the samples could be termed as acid rain. Calcium, Potassium, Sodium and Sulphur had a mean concentration of trace metal which was measured to be greater than $100 \mu \mathrm{g} / \mathrm{L}$; concentrations of Aluminium and Magnesium were between 1-100 $\mu \mathrm{g} / \mathrm{L}$ while Silicon and Strontium were found to be below detection limit. This study therefore reveals that the rainwater samples collected at New Benin and Ring Road were found to record the highest contamination of trace metal concentration as compared to other sampling sites.
\end{abstract}

Keywords: Inductively Coupled Plasma - Optical Emission Spectrometry (ICP-OES), trace metals, metropolis and rainwater sample.

\section{INTRODUCTION}

Rainwater is an important source of water especially for those that live in rural areas, where the use of water is limited due to scarcity or where surface and underground water quality is poor. In many areas, rainwater is still considered as a safe and suitable source of potable drinking water, and it is commonly used as such [1].

The massive increase in chemical utilization due to recent development in science and technology has greatly increased different contaminant present in water generally, regardless of its source.

As noted by [2], the concentration of pollutants correlated with the industrial activities in the metropolis indicates that these chemicals are mostly odourless, colourless and tasteless and most importantly are hazardous to man. In an industrial area, there is possibility of acid rain due to the constant emission of toxic elements into the atmosphere [2]. Rainwater is naturally acidic due to carbon dioxide in the atmosphere.

Changes in air pollutants in the lower atmosphere have important implications in the environment. Factors that influence the concentrations of these pollutants are important for understanding the interactions between tropospheric composition and rain water quality. The air mass trajectories with local-scale atmospheric measurements like wind direction and dust load give an insight to the chemical composition of precipitation. A majority of the anthropogenic and natural material that is loaded to the atmosphere is 
washed out by rainwater [3; 4]. Many of the trace elements found in the atmosphere are as a result of combustion of fossil fuels, these include additives such as lead in gasoline, processing of earth materials for manufacturing cements, and burning of waste materials [5].

In Benin City, the atmosphere is loaded with carbon dioxide origination from vehicular activities which influence rainwater quality.

Atmospheric deposition of trace elements derived from natural, geochemical and anthropogenic sources is the major pathway for the up-take of elements into aquatic systems. Pollutants released to the atmosphere as gases and aerosols from human activities are transported and deposited several kilometers away from their source; being removed by dry or wet deposition, with its consequences on living organisms in the ecosystems [6].

The chemistry of trace elements in the atmosphere is influenced by different sources of gases and aerosols, therefore, some elements present in the atmosphere can be originated in natural (biogenic emissions), geochemical (like marine aerosol and crustal) or anthropogenic sources. This paper therefore evaluates the trace metal concentration of rain water harvested from different parts of Benin metropolis; this will provide information on the status of rainwater in the areas.

\section{MATERIALS AND METHOD}

\section{Study Area/Sample Collection}

The samples of rainwater were collected from four different areas such as Ring Road, New Benin, University of Benin Campus and Oluku all located in Benin metropolis. It was ensured that the samples were representative of fresh rainwater to be examined and that no accidental contaminations occurred during sampling. All the 1 (one) litre containers used to collect rainwater sample for analysis were washed with detergent and rinsed with tap water followed by distilled water. The rainwater samples were collected in clean 1(one) litre plastic containers by placing a clean bowl on a raised platform in an open environment in other to ensure that the water had no contact with any object. The bowl used to collect the rainwater samples was only placed just before the rain started and removed immediately after downpour into the plastic containers. This was to avoid other dry atmospheric deposition. Sampling was done in September and October.

Immediately after each sample collection, the temperature and $\mathrm{pH}$ were measured insitu with a thermometer and digital $\mathrm{pH}$ meter of Model: EXTECH ExStick EC500. After which they were taken to the analytical laboratory. All samples were analyzed as soon as possible after collection or stored at a temperature of $4^{0} \mathrm{C}-5^{0} \mathrm{C}$, according to recommendations given by the standard methods. A Conductivity meter of model: HACH C0150 was used to measure the conductivity of the rainwater sample in $\mu$ Scm- ${ }^{1}$. 
Table 1: Rainwater sampling sites and description

\begin{tabular}{|c|c|c|}
\hline $\mathrm{S} / \mathrm{N}$ & Site Code & Site Description \\
\hline 1 & RGR & $\begin{array}{l}\text { Ring Road commercial hub of Benin metropolis : } 3 \text { metres from ring road with high traffic } \\
\text { volume and commercial activities }\end{array}$ \\
\hline 2 & NWB & $\begin{array}{l}\text { New Benin Market and Motor parks: New Benin road junction, where commercial activities } \\
\text { (markets) take place, small scale industries and high traffic emissions (presence of different } \\
\text { motor parks). }\end{array}$ \\
\hline 3 & OLK & Bottling Company of 7UP: Oluku, an Industrial area; By 7up Bottling Company \\
\hline 4 & EEC & $\begin{array}{l}\text { Premises of the Administrative Block Complex of the National Centre for Energy and } \\
\text { Environment (NCEE) situated in the University of Benin }\end{array}$ \\
\hline 5 & CAP & Capitol: Pristine Environment and Residential Area with no human activities (Control site) \\
\hline
\end{tabular}

RGR: Ring Road

NWB: New Benin Market

EEC: National Centre for Energy and Environment
OLK: Oluku, 7up bottling Company

CAP: Capitol,Uniben

\section{TRACE METALS DETERMINATION}

The PerkinElmer Optima 5300DV inductively coupled plasma - optical emission spectrometry (ICP-OES) with ASX-510 AutoSampler was used to determine trace metals. After the preparation of the calibration standards and samples, each of the samples were then transferred into small plastic sample containers including the blank solution which is $2 \%$ of nitric acid (solvent) minus the analyte of interest which is the rainwater samples, was also made. The blanks are usually used to complete the calibration of the instrument and calculate the limit of detection (LOD). For $10 \mathrm{ml}$ of the rainwater samples, $2-3 \mathrm{drops}$ of $2 \% \mathrm{HNO}_{3}$ was added and set up for running. In this case, an auto sampler was employed. All of these were placed accordingly in the auto sampler tubes or tray which were numbered and then run with the PerkinElmer Optima 5300DV inductively coupled plasma - optical emission spectrometry (ICP-OES). The blank was initially run on the ICP-OES followed by the certified reference material (CRM) and standards, then blank again, and then the rainwater samples. In running the standards, the least concentrated is always analyzed first in ascending order to the most concentrated. The next step in the development of the analysis methodology was to program the instrument, using the computer software provided with the instrument, to perform the data collection, handling and processing steps, this was left to run simultaneously. The results were then measured in part per billion (ppb) and printed out. 


\section{PRESENTATION OF RESULT AND DISCUSSION}

The mean concentration of the physicochemical analysis of the rainwater samples collected in September and October are presented in Tables 2 and 3 below:

Table 2: Mean Values of Temperature, pH, And Conductivity

\begin{tabular}{|l|l|l|l|l|l|l|}
\hline $\begin{array}{l}\text { Sample } \\
\text { Sites }\end{array}$ & RGR & NWB & EEC & OLK & CAP & $\begin{array}{l}\text { WHO Guidelines } \\
\text { for drinking water } \\
\text { quality }\end{array}$ \\
\hline $\begin{array}{l}\text { Temperature } \\
{ }^{0} \mathrm{C}\end{array}$ & 26.1 & 27.30 & 27.05 & 26.40 & 25.6 & $20-32$ \\
\hline $\mathrm{pH}$ & 5.56 & 5.51 & 6.18 & 5.47 & 6.76 & $6.50-8.50$ \\
\hline $\begin{array}{l}\text { Conductivity } \\
(\mu \mathrm{S} / \mathrm{cm})\end{array}$ & 10.05 & 83.15 & 7.65 & 5.65 & 8.10 & 1400.00 \\
\hline
\end{tabular}


Table 3: ICP-OES Mean Values of Trace Metals of Rainwater Samples

\begin{tabular}{|c|c|c|c|c|c|c|c|c|c|}
\hline Trace Metals & $\begin{array}{l}\text { Wavelength } \\
(\mathrm{nm})\end{array}$ & $\begin{array}{l}\text { Limit of } \\
\text { Detection } \\
\text { (LOD) }\end{array}$ & RGR & NWB & EEC & OLK & CAP & $\begin{array}{l}\text { WHO Guidelines for } \\
\text { drinking } \\
\text { quality }\end{array}$ & $\begin{array}{l}\text { NESREA } \\
\text { Standards for } \\
\text { quality of } \\
\text { Drinking water }\end{array}$ \\
\hline Aluminum $\quad(\mu \mathrm{g} / \mathrm{L})$ & 396.153 & 1.022 & 30.421 & 189.897 & 3.028 & 12.767 & 9.978 & - & - \\
\hline Calcium $(\mu \mathrm{g} / \mathrm{L})$ & 317.933 & 1.623 & 1239.101 & 910.400 & 371.690 & 187.360 & 316.926 & 200,000 & 200,000 \\
\hline Potassium $(\mu \mathrm{g} / \mathrm{L})$ & 766.490 & 1.721 & 294.494 & 216.434 & 217.213 & 137.379 & 303.664 & - & - \\
\hline Magnesium $(\mu \mathrm{g} / \mathrm{L})$ & 279.07 & 0.394 & 65.396 & 100.441 & 49.969 & 25.826 & 18.280 & 200,000 & 200,000 \\
\hline Sodium $(\mu \mathrm{g} / \mathrm{L})$ & 589.592 & 2.105 & 813.186 & 293.566 & 339.381 & 129.342 & 123.368 & 200,000 & 200,000 \\
\hline Silicon $(\mu \mathrm{g} / \mathrm{L})$ & 251.611 & 4.847 & BDL & $\mathrm{BDL}$ & BDL & $\mathrm{BDL}$ & $\mathrm{BDL}$ & - & - \\
\hline $\operatorname{Tin}(\mu \mathrm{g} / \mathrm{L})$ & 189.927 & 6.851 & BDL & BDL & BDL & BDL & BDL & - & - \\
\hline Strontium $(\mu \mathrm{g} / \mathrm{L})$ & 407.771 & 0.019 & 0.969 & BDL & BDL & BDL & BDL & - & - \\
\hline Boron $(\mu \mathrm{g} / \mathrm{L})$ & 249.677 & 39.504 & 81.948 & 48.961 & 93.797 & 88.128 & 132.922 & 2400 & - \\
\hline Sulphur $(\mu \mathrm{g} / \mathrm{L})$ & 180.669 & 23.863 & 456.402 & 446.411 & 224.734 & 118.509 & 55.487 & - & - \\
\hline
\end{tabular}


The mean values of $\mathrm{pH}$ for all the samples of rainwater at different locations were acidic with ranges of 5.47- 6.76 as shown in table 2. In previous work, samples of rainwater collected from some economic hub (industrial area) of Lagos State had a slight acidic mean $\mathrm{pH}$ range values of 6.57- 6.9 [7], which is not as acidic as that collected in Benin metropolis. The highest acidic level was at OLK, with pH mean value of 5.47, followed by NWB (5.51), RGR (5.56) and EEC (6.18) which were however lower than the standard of WHO Guidelines for drinking water. This however, indicates that the various locations are highly polluted as a result of anthropogenic activities being carried out in the areas such as OLK which is an industrial area and NWB, a commercial area. Samples of rainwater collected at CAP, recorded the least acidic $\mathrm{pH}$ mean value of 6.76 which was within the WHO recommended levels. The result from CAP which is the control site therefore indicates that there is little or no commercial/industrial activity (sparsely populated). The mean values of conductivity ranges from $5.65-83.15 \mu \mathrm{S} / \mathrm{cm}$ which is within the WHO for drinking water standard.

For trace metal analysis using the ICP-OES as shown in table 3, The concentration of Aluminum (Al) has mean values ranging from 3.028-189.897 $\mu \mathrm{g} / \mathrm{L}$ with RGR $(189.897 \mu \mathrm{g} / \mathrm{L})$ and NWB $(30.421 \mu \mathrm{g} / \mathrm{L})$ having the highest mean concentration found in rainwater collected. EEC $(3.028 \mu \mathrm{g} / \mathrm{L})$ recorded the lowest concentration of Aluminum (Al) while RGR and NWB had the highest mean concentration values of Calcium $(\mathrm{Ca})(1239.101 \mu \mathrm{g} / \mathrm{L})$ and $(910.4 \mu \mathrm{g} / \mathrm{L})$ respectively. The least mean concentration of Calcium $(\mathrm{Ca})$ was observed at OLK with value of $187.36 \mu \mathrm{g} / \mathrm{L}$. Table 2 shows that Calcium ranges from 187.36-1239.101 $\mu \mathrm{g} / \mathrm{L}$. The mean

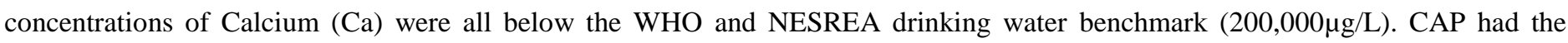
highest mean concentration of Potassium with $303.664 \mu \mathrm{g} / \mathrm{L}$ and OLK with the lowest mean concentration of $137.371 \mu \mathrm{g} / \mathrm{L}$. Potassium (K) and Sodium (Na) occur in rainwater at concentrations well below those of health concern, thus does not have a WHO and NESREA benchmark. Potassium ranged from 137.379 - 303.664 $\mu \mathrm{g} / \mathrm{L}$ while Sodium (Na) and Magnesium (Mg) varied with ranges of $123.368-813.186 \mu \mathrm{g} / \mathrm{L}$ and $18.280-100.441 \mu \mathrm{g} / \mathrm{L}$ respectively. NWB had the highest mean concentration of Magnesium $(\mathrm{Mg})$ with value $100.441 \mu \mathrm{g} / \mathrm{L}$ while RGR followed with mean concentration of Magnesium $(\mathrm{Mg})$ with value $65.396 \mu \mathrm{g} / \mathrm{L}$. EEC, OLK and CAP were all below $50 \mu \mathrm{g} / \mathrm{L}$. However, all mean concentrations for Magnesium $(\mathrm{Mg})$ were far below the WHO and NESREA drinking water standards.

The samples of rainwater collected from different locations of Benin metropolis were found to be less than the limit of detection (LOD) for Silicon (Si) and Tin (Sn). RGR was observed to have a mean concentration of Strontium (Sr) with value of $0.969 \mu \mathrm{g} / \mathrm{L}$ while for other locations, it was observed to be below the limit of detection (LOD) of the ICP-OES employed for trace metal analysis. Thus, Strontium (Sr) was not identified for samples of rainwater collected for other locations.

RGR and NWB with values of $(456.402 \mu \mathrm{g} / \mathrm{L})$ and $(446.411 \mu \mathrm{g} / \mathrm{L})$ respectively had a high level of mean concentrations of Sulphur (S) recorded. The high concentration of Sulphur (S) in this locations are probably from high traffic volume due to commercial activities and have led to vehicular combustion of fossil fuels from exhaust pipes and sour gas releasing Sulphur oxides to the atmosphere, 
therefore polluting the environment. EEC, OLK and CAP recorded lower levels of Sulphur (S) with values $224.734 \mu \mathrm{g} / \mathrm{L}$, $118.509 \mu \mathrm{g} / \mathrm{L}$ and $55.487 \mu \mathrm{g} / \mathrm{L}$ respectively.

The trace metals in the order of $\mathrm{Ca}>>\mathrm{Na}>\mathrm{S}>\mathrm{K}>\mathrm{Al}>\mathrm{Mg}$ which are probably present in animal and plant cells/tissues and are a necessary part of nutrition and physiology are not of health concern at levels found in drinking water. Anambra, Nigeria [8], Hyderabad, India [9], Istanbul [10] and Turkey [11], revealed trace metal concentration of samples of rainwater collected. It can therefore be stated that the rainwater harvested in Benin metropolis recorded high concentration for most trace metals analyzed, resulting in more pollution of the rainwater and exposing man and the environment to harmful substances.

\section{CONCLUSION}

This paper has displayed from the results that the acidic level of rainwater from some locations in Benin metropolis could be termed acid rain because of the $\mathrm{pH}$ values at (OLK) and (RGR) which is an industrial area and high volume of traffic due to commercial activities taking place in that area.

There was a high level of sulphuric acid in the sample of rain water collected which probably showed a good correlation of high levels of acid and sulphur. The high levels of acid also correlate with levels of nitrate and sulphate.

Table 3 displayed the highest level concentration of trace metal of rainwater samples collected from NWB and RGR as compared to other areas where samples were collected. However, trace metals found in drinking water that are of no health concern where all within the drinking water limits of WHO and NESREA

The parameters of rainwater quality displayed in table 3 reveals that rainwater collected from high traffic density areas (RGR) and commercial hub (NWB) areas are polluted by emissions from small scale industries and exhaust of automobiles, therefore rainwater in Benin metropolis is not a safe and suitable source of potable drinking water. The results from this paper have provided information on the quality of rainwater in Benin metropolis.

\section{Acknowledgement}

The rainwater samples were analysed at the University of Hull, United Kingdom with the assistance of Analytical Chemistry Trust Fund (ACTF) for developing World Countries. Acknowledgement also goes to the National Centre for Energy and Environment (NCEE), Energy Commission of Nigeria for the opportunity to complete this work.

\section{References}


1. Vikaskumar G. Shah, Hugh R. Dunstan, Phillip M. Geary, Peter Coombes, Timothy K. Roberts, and Tony Rothkirch (2007). Comparisons of water quality parameters from diverse catchments during dry periods and following rain events Water Research, Vol. 41 (16): 3655-3666.

2. Ayodele, J. T. and Abubakar, M. (1998). Trace metals in Tiga Lake, Kano, Nigeria. Trop. Environ. Rev. Vol. 3: 230 - 237.

3. Başak, B. and Alagha, O. (2004). Trace metals solubility in rainwater: evaluation of rainwater quality at a watershed area, Istanbul. Environmental Monitoring Assessment. Vol. 167(1-4):493-503.

4. Charlson, R. J. and Rodhe, H. (1982). Factors controlling the acidity of natural rainwater. Nature Vol. 295 , $683-685$.

5. Al-Momani, I. F. (2003). Trace elements in atmospheric precipitation at Northern Jordan measured by ICP-MS: acidity and possible sources. Atmospheric Environment Vol. 37, 4507-4515.

6. Steinnea, E. (1990). Lead, cadmium and other metals in Scandinavian surface waters, with emphasis on acidification and atmospheric deposition, Envir. Toxicol. Chem, Vol. 9, 825.

7. Dinrifo, R.R., Babatunde, S.O.E., Bankole, Y.O., Demu, Q.A. (2010). Physicochemical Properties of Rain water collected from some Industrial areas of Lagos State, Nigeria. European Journal of Scientific Research Vol.41 No.3, pp.383-390.

8. Egereonu, U. U. (2006). Physico-chemical assessment of rainwater from two raingauge station in the rain forest region Anambra Nigeria, Journal of Chemical Society of Nigeria Vol. 31 No.1-2. Pp 43-47.

9. Satyanarayanan, M., Balaram, V., Parijat, R. and Rao, T. G. (2006). Interlaboratory Collaborative analysis of real time rainwater samples obtained at the Geochemical Laboratory, National Geophysical Research Institute, Hydrabad, India. Current Science, Vol. 91, No. 2

10. Başak, B. and Alagha, O. (2010). Trace metals solubility in rainwater: evaluation of rainwater quality at a watershed area, Istanbul. Environmental Monitoring Assessment. 167(1-4):493-503.

11. Kaya, G., and Tuncel, G. (1997). Trace element and major ion composition of wet and dry deposition in Ankara, Turkey. Atmospheric Environment, Vol. 31, 3985-3998. 